\title{
Endothelial cell signalling supports pancreatic beta cell function in the rat
}

\author{
Å. Johansson • J. Lau • M. Sandberg • L. A. H. Borg • \\ P. U. Magnusson • P.-O. Carlsson
}

Received: 13 October 2008 / Accepted: 14 July 2009/Published online: 11 August 2009

(C) Springer-Verlag 2009

\begin{abstract}
Aims/hypothesis The proximity of endothelial cells and beta cells in islets by necessity means that they are exposed to each other's products. Whereas islet endothelial cells require signals from beta cells to function properly, endothelin-1, thrombospondin-1 and laminins, among others, have been identified as endothelial-derived molecules, although their full effects on beta cells have not been explored. We tested the hypothesis that islet endothelialderived products affect beta cell function.

Methods Endothelial cells from rat islets were proliferated and purified. Endothelium-conditioned culture medium (ECCM) was obtained by maintaining the endothelial cells in culture medium. Islet function was evaluated following exposure of cultured islets to standard culture medium or ECCM. Changes in mRNA levels for key beta cell metabolic enzymes were also measured in islets after ECCM exposure.
\end{abstract}

Electronic supplementary material The online version of this article (doi:10.1007/s00125-009-1485-6) contains supplementary material, which is available to authorized users.

Å. Johansson $(\bowtie) \cdot$ J. Lau $\cdot$ M. Sandberg · L. A. H. Borg • P.-O. Carlsson

Department of Medical Cell Biology, Uppsala University,

Box 571, SE-751 23 Uppsala, Sweden

e-mail: asa.johansson@mcb.uu.se

P. U. Magnusson

Department of Oncology, Radiology and Clinical Immunology,

Division of Clinical Immunology, The Rudbeck Laboratory,

Uppsala University,

Uppsala, Sweden

P.-O. Carlsson

Department of Medical Sciences, Uppsala University,

Uppsala, Sweden
Results Glucose-stimulated insulin release and islet insulin content were markedly enhanced by exposure to ECCM. This was at least partly explained by improved mitochondrial function, as assessed by glucose oxidation and an upregulation of the mitochondrial gene for glycerol-3phosphate dehydrogenase ( $m G p d h$ [also known as $G p d 2$ ]), combined with upregulation of the rate-limiting enzyme in the glycolysis, glucokinase, in the islets. The intracellular degradation of insulin was also decreased in the islets. Islet endothelial cells produced laminins, and the positive effects of islet endothelial cells were prevented by addition of a neutralising antibody to the $\beta 1$-chain of laminin. Addition of exogenous laminin stimulated islet function.

Conclusions/interpretation This study provides proof of principle that endothelial cells can affect the function of beta cells in their vicinity and that this is at least partially mediated by laminins.

Keywords Endothelial cells $\cdot$ Beta cells $\cdot$ Laminin

$\begin{array}{ll}\text { Abbreviations } & \\ \text { BS-1 } & \text { Bandeiraea simplicifolia } \\ \text { CM } & \text { Culture medium } \\ \text { COX-2 } & \text { Cyclooxygenase 2 } \\ \text { DiI-Ac-LDL } & \begin{array}{l}\text { Dioctadecyl indocarbocyanine acetylated } \\ \text { LDL }\end{array} \\ \text { ECCM } & \text { Endothelium-conditioned culture medium } \\ \text { ECM } & \text { Endothelial culture medium } \\ \text { ET } & \text { Endothelin } \\ \text { HDMEC } & \text { Human dermal microvascular endothelial } \\ & \text { cells } \\ \text { HGF } & \text { Hepatocyte growth factor } \\ \text { LM } & \text { Laminin } \\ \text { MSC } & \text { Mesenchymal stem cells } \\ \text { RBMVEC } & \text { Rat brain microvascular endothelial cells }\end{array}$


$\alpha$-SMA $\quad$ Alpha smooth muscle actin

TSP Thrombospondin

VE-cadherin Vascular endothelial cadherin

\section{Introduction}

Endothelium has long been considered as a form of plumbing, being important only for transport functions. However, it has in recent years become obvious that endothelial cells produce a number of growth factors, cytokines and other substances that may affect not only the endothelial cells themselves, but also surrounding cells [1]. The importance of endothelial cell signalling for parenchymal cells was first demonstrated for liver and pancreatic organogenesis [2, 3], and growth of adult prostate [4] and liver [5]. Whether endothelial cells may not only affect parenchymal differentiation and growth, but also parenchymal function through paracrine signalling has been less studied [6, 7]

The pancreatic islets in the adult are among the most vascularised of all organs in the body with a unique dense glomerular-like angioarchitecture. This means that in the islet, each beta cell is surrounded by at least one islet endothelial cell, and therefore these cells by necessity are exposed to each other's products [8]. Indeed, the high islet vascular density and the vascular phenotype, with a great number of fenestrations, is induced and maintained by secretion of vascular endothelial growth factor from the beta cells [9-11]. Recently, we and others have shown that endothelial cells signal back and contribute to maintenance [12], and during certain conditions even expansion, of the adult beta cell mass [6,13-15]. In the present study, we tested the hypothesis that islet endothelial cell products may directly influence beta cell function.

\section{Methods}

Animals Adult, inbred male Wistar-Furth rats purchased from Scanbur (Sollentuna, Sweden) were used. The animals had free access to pelleted food and autoclaved tap water. All experimental procedures were approved by the Animal Ethics Committee for Uppsala University.

Chemicals All chemicals were purchased from SigmaAldrich (St Louis, MO, USA) unless otherwise mentioned.

Islet isolation Islets were isolated by using collagenase digestion followed by separation on a density gradient. Briefly, under deep anaesthesia with sodium pentobarbital (Apoteket, Gothenburg, Sweden; 200 mg/kg i.p.), a laparatomy was performed and the pancreas exposed. After ligation at the ampulla of Vater, $5 \mathrm{ml}$ collagenase solution (from Clostridium histolyticum; F. Hoffman-La Roche, Basel, Switzerland) was injected into the pancreas via the common bile duct. The animal was killed and the pancreas dissected from surrounding tissues, removed and incubated in a water bath for approximately $16 \mathrm{~min}$ at $37^{\circ} \mathrm{C}$. The islets were separated by a density gradient (Histopaque-1077) centrifugation at $900 \times \mathrm{g}$ for $22 \mathrm{~min}$. After washing, islets were handpicked and groups of 150 islets were maintained free-floating at $37^{\circ} \mathrm{C}\left(\mathrm{air} / \mathrm{CO}_{2} ; 95: 5\right)$ in culture medium (CM) consisting of RPMI 1640 supplemented with Lglutamine $(2 \mathrm{mmol} / \mathrm{l})$, benzylpenicillin $(100,000 \mathrm{U} / \mathrm{l}$; Hoffman-La Roche), streptomycin $(0.1 \mathrm{~g} / \mathrm{l}$; Hoffman-La Roche) and 10\% (vol./vol.) FCS for 4-6 days. CM was changed every $48 \mathrm{~h}$.

Isolation of islet endothelial cells Outgrowth of islet stromal cells on a collagen matrix was stimulated using a modification of a previously described protocol [16]. Briefly, 20 hand-picked, apparently clean islets were transferred onto a collagen matrix (1.8 mg collagen type $1 / \mathrm{ml}$; Nutacon, Leimuden, the Netherlands) in a 24 well culture dish. Islets were cultured at $37^{\circ} \mathrm{C}\left(\mathrm{air} / \mathrm{CO}_{2} ; 95: 5\right)$ in $1 \mathrm{ml}$ endothelial CM (ECM), this being CM with $20 \%$ (vol./vol.) FCS and with $100 \mu \mathrm{g}$ endothelial cell growth supplement $/ \mathrm{ml}$.

Expanding cells were detached before reaching confluence with $0.25 \%$ (wt $/ \mathrm{vol}$.) trypsin-EDTA solution for $<5 \mathrm{~min}$ at room temperature. The suspension was washed twice in CM. The endothelial cells were extracted from the cell suspension by a Dynabead (Dynal Biotech, Oslo, Norway) method previously described [17]. By the use of Bandeiraea (Griffonia) simplicifolia (BS-1)-coated Dynabeads, endothelial cells were separated from contaminating cells, generating a purity of $>90 \%$ [13].

Purity and characterisation of endothelial cell preparations As a control of endothelial cell purity, samples of endothelial cells were trypsinised, centrifuged onto poly-Llysine-coated glass slides, fixed in $4 \%$ (vol./vol.) paraformaldehyde for $2 \mathrm{~h}$, and subsequently dehydrated. The slides were stained to detect endothelium with a rat anti-CD31 antibody (HyCult Biotechnology, Uden, the Netherlands) using the EnVision ${ }^{+}$system (Dako, Glostrup, Denmark). Antigen retrieval was performed by boiling for $20 \mathrm{~min}$ with Target Retrieval Solution (pH 9.0; Dako) in a microwave oven $(750 \mathrm{~W})$. The slides were counterstained with haematoxylin. After staining, the fraction of CD31positive cells was manually counted in a light microscope $(\times 400)$. Isolated islet endothelial cells were also cultured on collagen-coated glass slides $(1.8 \mathrm{mg}$ collagen type $1 / \mathrm{ml}$; Nutacon) and fixed in zinc fixative (Becton Dickinson 
Biosciences, San Jose, CA, USA [BD]) for $30 \mathrm{~min}$. After incubation with primary antibodies against CD31 (Chemicon, Chandlers Ford, UK), vascular endothelial cadherin (VE-cadherin; Santa Cruz Biotechnology, Santa Cruz, CA, USA) and alpha smooth muscle actin ( $\alpha$-SMA) the slides were washed and incubated with goat-anti-mouse Alexa 568 (Molecular Probes, Eugene, OR, USA). The slides were then washed, stained with Hoechst, and mounted with Fluoromount-G (Southern Biotechnology, Birmingham, AL, USA). Rat mesenchymal stem cells (MSC) and rat brain microvascular endothelial cells (RBMVEC; Cell Applications, San Diego, CA, USA) were used as negative and positive controls, respectively.

To further characterise the isolated endothelial cells, uptake of fluorescently labelled dioctadecyl indocarbocyanine acetylated LDL (DiI-Ac-LDL; Invitrogen, Lidingö, Sweden) was investigated as endothelial cells have an increased metabolism of Ac-LDL in comparison with supportive stromal cells [18]. Cells cultured on collagencoated glass slides (1.8 mg collagen type $1 / \mathrm{ml}$; Nutacon) were incubated with $20 \mu \mathrm{g} / \mathrm{ml}$ DiI-Ac-LDL for $4 \mathrm{~h}$ at $37^{\circ} \mathrm{C}$. The slides were subsequently washed, fixed in zinc fixative (BD), stained with Hoechst and mounted with Fluoromount G (Southern Biotechnology, Birmingham, AL, USA). Rat MSC and human dermal microvascular endothelial cells (HDMEC; PromoCell, Heidelberg, Germany) were used as negative and positive controls, respectively. The cells were analysed using a confocal microscope (C-1/TE200U; Nikon, Tokyo, Japan).

Endothelium-conditioned CM Dynabead-purified endothelial cells were cultured for 2 days in ECM as described above. At this time point the endothelial cells were in exponential growth, but had not reached confluence. The wells were washed with CM to remove all ECM and fresh $\mathrm{CM}$ was then added to the wells. The medium was collected $24 \mathrm{~h}$ later and centrifuged for $2 \mathrm{~min}$ at $600 \mathrm{~g}$ to remove cells. The endothelium-conditioned medium, hereafter termed ECCM, was then stored at $-70^{\circ} \mathrm{C}$.

ECCM with cyclooxygenase 2 (COX-2) inhibition The endothelial cells were treated as mentioned above, but the $\mathrm{CM}$ contained $1 \mu \mathrm{mol} / 1$ of the COX-2 inhibitor rofecoxib (4-[4-(methylsulfonyl)phenyl]-3-phenyl-2(5H)-furanone) (Kemprotec, Middlesbrough, UK) or DMSO as vehicle control. The medium was collected, centrifuged for $2 \mathrm{~min}$ at $600 \times g$ to remove cells and stored at $-70^{\circ} \mathrm{C}$.

Islet incubation in ECCM Twenty islets were precultured for 4-7 days in CM, and subsequently cultured in $1 \mathrm{ml}$ of control CM or ECCM in a 24 well culture dish for $24 \mathrm{~h}$. The reason for the pre-culture period was to minimise remnant islet endothelial cells, as studies have shown that $\sim 90 \%$ of the intra-islet endothelial cells disappear after 4 days in culture $[6,19]$.

Glucose-stimulated insulin release Groups of ten islets were transferred in triplicates to glass vials containing $250 \mu \mathrm{l}$ Krebs-Ringer bicarbonate buffer supplemented with $10 \mathrm{mmol} / 1 \mathrm{HEPES}$ and $2 \mathrm{mg} / \mathrm{ml}$ BSA (MP Biomedicals, Irvine, CA, USA) (hereafter referred to as KRBH buffer). The KRBH buffer contained $1.67 \mathrm{mmol} / \mathrm{l} \mathrm{D}$-glucose during the first hour of incubation at $37^{\circ} \mathrm{C}\left(\mathrm{O}_{2} / \mathrm{CO}_{2} ; 95: 5\right)$. The medium was removed and replaced by $250 \mu \mathrm{KRBH}$ supplemented with $16.7 \mathrm{mmol} / \mathrm{l}$ glucose and the incubation continued for a second hour. The medium was retrieved and stored at $-20^{\circ} \mathrm{C}$. To measure the total insulin content and DNA content, the islets were harvested, pooled in groups of 30 , and homogenised by sonication in $200 \mu$ l redistilled water. A fraction of the homogenate was mixed with acidethanol $(0.18 \mathrm{~mol} / 1 \mathrm{HCl}$ in $95 \%$ [vol./vol.] ethanol), from which insulin was extracted overnight at $4^{\circ} \mathrm{C}$. Samples were then stored at $-20^{\circ} \mathrm{C}$ until insulin and DNA measurement (see below). In separate experiments, soluble laminin (LM)-111 ( $\alpha 1 \beta 1 \gamma 1$; according to new LM nomenclature [20]) $(30 \mu \mathrm{g} / \mathrm{ml})(\mathrm{BD})$, neutralising antibodies to thrombospondin-1 (TSP-1; $1 \mu \mathrm{g} / \mathrm{ml}$ ) (LabVision, Fremont, CA, USA), hepatocyte growth factor (HGF; $1 \mu \mathrm{g} / \mathrm{ml}$ ) (R\&D Systems, Minneapolis, MN, USA) or the $\beta 1$-chain of LM $(18 \mu \mathrm{g} / \mathrm{ml}$; Clone 3E5, Catalogue number MAB2041; Millipore, Solna, Sweden), or the endothelin $\mathrm{A}\left(\mathrm{ET}_{\mathrm{A}}\right)$ and endothelin $\mathrm{B}\left(\mathrm{ET}_{\mathrm{B}}\right)$ receptor antagonists BQ$123(10 \mu \mathrm{mol} / \mathrm{l})$ and BQ-788 $(1 \mu \mathrm{mol} / \mathrm{l})($ Bachem UK, St Helens, UK), were added to the high-glucose medium.

Insulin measurement After appropriate dilution, insulin concentrations in incubation medium and homogenates were determined by a commercial insulin ELISA (Mercodia, Uppsala, Sweden).

DNA measurement After appropriate dilution, the homogenates were used for DNA measurements by fluorophotometry (PicoGreen dsDNA Quantitation Kit; Molecular Probes).

Glucose oxidation rate Islet glucose oxidation rates were determined according to a previously described method [21]. Briefly, triplicates of ten islets were transferred to glass vials containing $100 \mu \mathrm{KRBH}$ supplemented with D- $\left[\mathrm{U}-{ }^{14} \mathrm{C}\right]$ glucose (GE Healthcare Life Sciences, Chalfont St Giles, UK) and non-radioactive D-glucose to a final glucose concentration of $16.7 \mathrm{mmol} / 1$ and a specific radioactivity of $18.5 \times 10^{6} \mathrm{~Bq} / \mathrm{mmol}$. The ${ }^{14} \mathrm{CO}_{2}$ produced was captured with Hyamine. After incubation for $90 \mathrm{~min}$ at $37^{\circ} \mathrm{C}\left(\mathrm{O}_{2} / \mathrm{CO}_{2} ; 95: 5\right)$, the oxidation was terminated by injection of $100 \mu \mathrm{l} 0.05 \mathrm{mmol} / \mathrm{l}$ antimycin $\mathrm{A}$ into the vials. The ${ }^{14} \mathrm{CO}_{2}$ generated by cell metabolism was released by 
the addition of $100 \mu \mathrm{l} 0.4 \mathrm{mmol} / 1 \mathrm{NaH}_{2} \mathrm{PO}_{4}(\mathrm{pH}$ 6.0) during a $120 \mathrm{~min}$ incubation. The radioactivity in the samples was then measured by liquid scintillation counting.

Islet (pro)insulin biosynthesis and total protein biosynthesis Groups of ten islets were incubated in duplicate for $2 \mathrm{~h}$ in $100 \mu \mathrm{l} \mathrm{Krebs-Ringer} \mathrm{buffer} \mathrm{containing} 2 \mathrm{mg} / \mathrm{ml} \mathrm{BSA}$, $16.7 \mathrm{mmol} / 1$ glucose and $1.85 \times 10^{9} \mathrm{~Bq} / \mathrm{mmol} \mathrm{L}-\left[3,4,5-{ }^{3} \mathrm{H}\right]$ leucine (American Radiolabeled Chemicals, St Louis, MO, USA) at $37^{\circ} \mathrm{C}$ in (air/ $\left./ \mathrm{CO}_{2} ; 95: 5\right)$. After incubation the islets were washed in Hanks' balanced salt solution containing $10 \mathrm{mmol} / \mathrm{l}$ non-radioactive leucine, and then sonicated in $200 \mu \mathrm{l}$ redistilled water. The islet homogenates were frozen before immunoprecipitation.

Insulin degradation Islet intracellular degradation of insulin was determined using a pulse-chase method. The islet proteins were labelled by maintaining about 150 islets in the presence of $5.5 \mathrm{mmol} / 1$ glucose and $1.5 \mathrm{GBq} / \mathrm{l} \mathrm{L}-$ $\left[3,4,5-{ }^{3} \mathrm{H}\right]$ leucine (American Radiolabeled Chemicals), yielding a specific radioactivity of $3.3 \mathrm{GBq} / \mathrm{mmol}$ in the medium during the $72 \mathrm{~h}$ incubation. The islets were then washed twice in non-radioactive medium, and duplicate groups of 15 islets were homogenised by sonication $(22 \mathrm{kHz}, 50 \mathrm{~W}$ ) for $10 \mathrm{~s}$ in $200 \mu \mathrm{l}$ of a $50 \mathrm{mmol} / \mathrm{l}$ glycine buffer $\mathrm{pH} 8.8$ containing $2.5 \mathrm{~g} / 1 \mathrm{BSA}$. The remaining islets were divided into two aliquots, which were incubated for $24 \mathrm{~h}$ without radioactivity in CM or ECCM. After the chase period, duplicates of 15 islets from both groups were homogenised by sonication in $200 \mu$ l glycine-BSA-buffer, and $100 \mu \mathrm{l}$ portions of the incubation medium were also retrieved. The islet homogenates and incubation medium were frozen before immunoprecipitation.

Immunoprecipitation Portions of $10 \mu \mathrm{l}$ from the islet homogenates and the $100 \mu \mathrm{l}$ medium samples from the islet incubations were mixed with $100 \mu \mathrm{l}$ of a $50 \mathrm{mmol} /$ 1 glycine buffer supplemented with $2.5 \mathrm{~g} / 1 \mathrm{BSA}$ and $1 \mathrm{ml} /$ 1 Triton X-100, and in duplicates supplied with $10 \mu \mathrm{l}$ of guinea pig anti-human insulin serum (Fitzgerald Industries International, Concord, MA, USA) or $10 \mu \mathrm{l}$ normal guinea pig serum (Harlan Sera-Lab, Loughborough, UK). The immune binding was allowed to proceed for $1 \mathrm{~h}$ at room temperature. Subsequently $50 \mu 1$ rProtein-A-Sepharose Fast Flow suspended in glycine-BSA-Triton X-100 buffer to a concentration of $110 \mathrm{ml} / \mathrm{l}$ was added and the material was tumbled for $15 \mathrm{~min}$ at room temperature and then centrifuged for $3 \mathrm{~min}$ at $4,000 \times g$. The Sepharose sediment with the anti-insulin-insulin complex was washed twice with $500 \mu \mathrm{l}$ glycine-BSA-Triton X-100 buffer and finally resuspended in $500 \mu \mathrm{l} 1 \mathrm{~mol} / 1$ acetic acid with $2.5 \mathrm{~g} / \mathrm{l} \mathrm{BSA}$. After addition of $4 \mathrm{ml}$ Ultima Gold scintillation fluid, the radioactivity was determined by a liquid-scintillation spectrometer (Wallac System 1400; Turku, Finland) using external standardisation. Non-specific binding was corrected for by subtracting the radioactivity bound by normal guinea pig serum from that precipitated by immune serum. For the analysis of total protein biosynthesis rate, two $10 \mu \mathrm{l}$ aliquots were taken from the water homogenate samples of sonicated islets and transferred to Eppendorf tubes. Glycine solution $(250 \mu \mathrm{l})$ was added to dilute the homogenate and $250 \mu \mathrm{l}$ of $10 \%$ (wt/vol.) trichloroacetic acid was added to precipitate the proteins. The samples were mixed vigorously and centrifuged $(10 \mathrm{~min}$ at $600 \mathrm{~g})$. The supernatant fraction was removed and the pellets dissolved in $2 \times 250 \mu \mathrm{l}$ of $0.15 \mathrm{~mol} / \mathrm{l} \mathrm{NaOH}$ and transferred to scintillation vials before $4 \mathrm{ml}$ Ultima Gold scintillation liquid was added and the samples counted in a liquid scintillation counter.

Gene expression analysis Isolation of total RNA was performed with an RNeasy Micro Kit (Qiagen, Hilden, Germany) and all the samples were treated with RNase-free DNase (Qiagen). Conversion of total RNA to cDNA was performed with reverse transcription system (Promega, Madison, WI, USA) using oligo $(\mathrm{dT})_{15}$ primers. The LightCycler System (Hoffman-La Roche), and detection with SYBR Green (SYBR Green JumpStart Taq ReadyMix), was used to amplify and analyse generated cDNA. TATA box binding protein (GenBank accession number D01034; CyberGene, Stockholm, Sweden), 5'-ACC CTT CAC CAA TGA CTC CTA TG-3', 5'-ATG ATG ACT GCA GCA AAT CGC-3', was used as housekeeping gene. PCR amplifications were performed in a total volume of $10 \mu \mathrm{l}$, containing $1 \mu \mathrm{l}$ of cDNA, $1 \mu \mathrm{l}$ of each primer (Tebu-Bio, Roskilde, Denmark or MWG Biotech, Edersberg, Germany) (see Electronic supplementary material [ESM] Table 1), $4 \mu \mathrm{l}$ CYBR Green JumpStart Taq ReadyMix and RNase-free water added to the final volume. Each RT-PCR run started with a denaturation at $94^{\circ} \mathrm{C}$ for $10 \mathrm{~s}$. Cycling variables were $94^{\circ} \mathrm{C}, 10 \mathrm{~s} ; 57^{\circ} \mathrm{C}, 15 \mathrm{~s}$; and $72^{\circ} \mathrm{C}, 8 \mathrm{~s}$.

Statistics For multiple comparisons, repeated measurements of ANOVA with Bonferroni's post hoc test was used. When only two groups were compared, Student's paired or unpaired $t$ test was applied as appropriate.

\section{Results}

Purity and characteristics of endothelial cell preparations CD31-staining was used to characterise the endothelial cells purified by BS-1-coated Dynabeads. Evaluation by manual counting showed that the cultured sorted cells contained $89 \pm 6 \%(n=6)$ of cells positive for the endothelial cell marker CD31. The purified isolated cell preparations were further validated as endothelial cells not only by 
positive staining for a second CD31 antibody (Fig. 1a), but also for VE-cadherin (Fig. 1b) and by induced uptake of DiI-Ac-LDL (Fig. 1c), as were HDMEC (Fig. 1a-c). Moreover, the vast majority of the isolated cells and RBMVEC were negative for the smooth muscle cell marker $\alpha$-SMA (Fig. 1d) while MSC were positive for $\alpha$-SMA (Fig. 1d) but negative for all the endothelial cell markers (Fig. 1a-c).

Insulin release The basal insulin release at $1.67 \mathrm{mmol} /$ 1 glucose did not differ between islets that had been exposed to ECCM or CM, whereas the response in insulin release to $16.7 \mathrm{mmol} / \mathrm{l}$ glucose was augmented in ECCMexposed islets (Fig. 2a). Control islets and ECCMincubated islets had similar DNA contents $(92.5 \pm 1.8 \mathrm{ng}$ DNA per ten islets vs $93.7 \pm 5.4$ ng DNA per ten islets; $n=6$ in both groups). Addition of neutralising antibodies against TSP-1, HGF or receptor antagonists to $\mathrm{ET}_{\mathrm{A}}$ and $\mathrm{ET}_{\mathrm{B}}$ could not prevent the augmentative effect of ECCM on glucosestimulated insulin release (Fig. 2 b, c). Likewise, there was no difference in insulin release from islets that had been exposed to ECCM with addition of a COX-2 inhibitor, compared with islets exposed to ECCM with DMSO as vehicle control. However, addition of a function-inhibiting antibody towards the $\beta 1$-chain of LM neutralised the positive effects of ECCM on glucose-stimulated insulin release (Fig. 2c). Moreover, there was an increase in insulin release from islets incubated in $\mathrm{CM}$ with an addition of LM-111 when compared with islets incubated in control CM (Fig. 2d).

Insulin content The total islet insulin content was increased in islets that had been exposed to ECCM (Fig. 3a). This augmentative effect of ECCM on insulin content could not be prevented by addition of neutralising antibodies to TSP-1 or HGF or receptor antagonists to $\mathrm{ET}_{\mathrm{A}}$ and $\mathrm{ET}_{\mathrm{B}}$ (Fig. 3b, c).

Fig. 1 Characterisation of isolated islet cells. EC, RBMVEC or HDMEC, and MSC stained for CD31 (red) (a), VE-cadherin (red) (b), DiI-Ac-LDL (red) (c) and $\alpha$-SMA (red) (d). Nuclei stained with Hoechst (blue). Scale bars, $50 \mu \mathrm{m}$
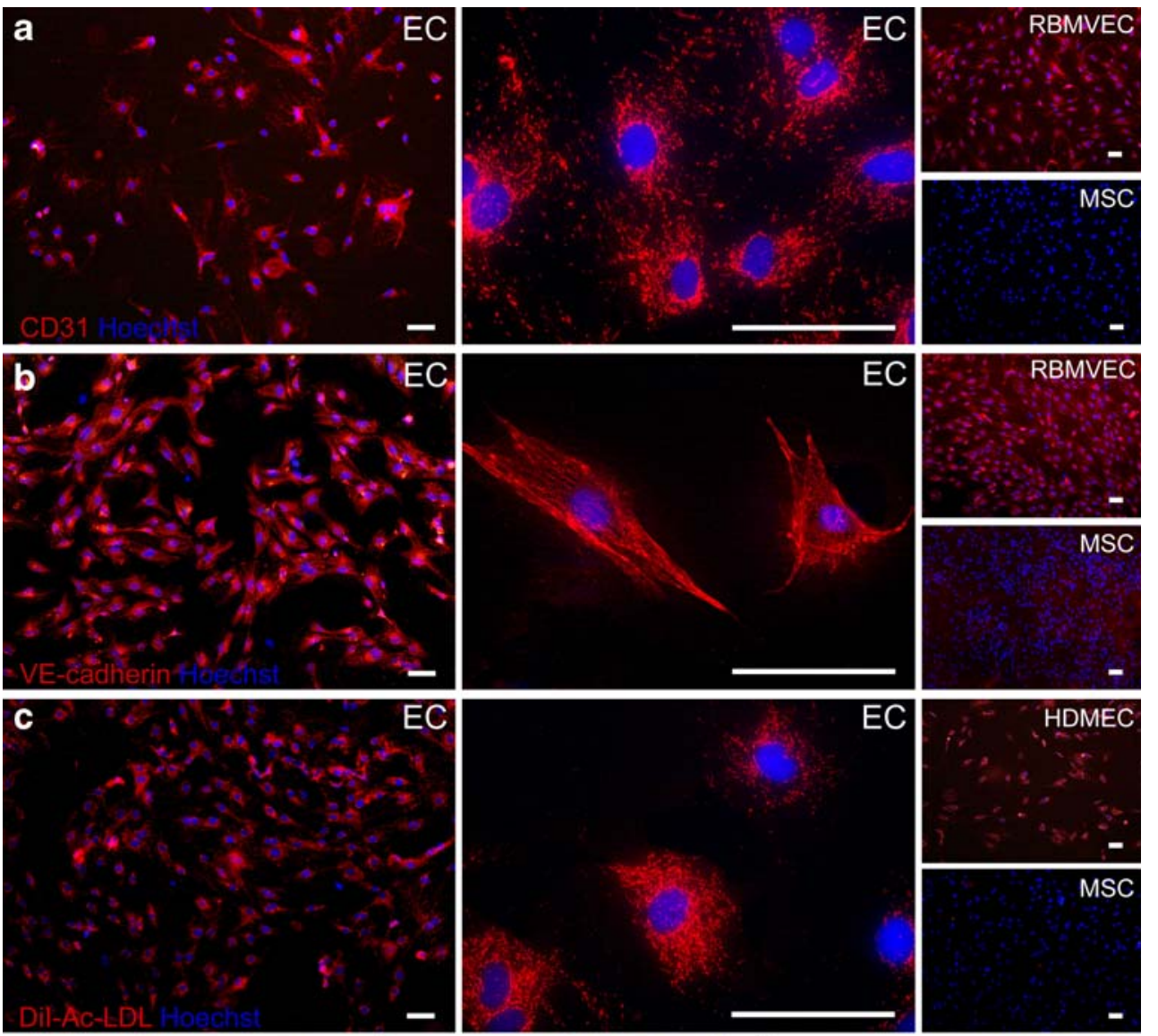

HDMEC
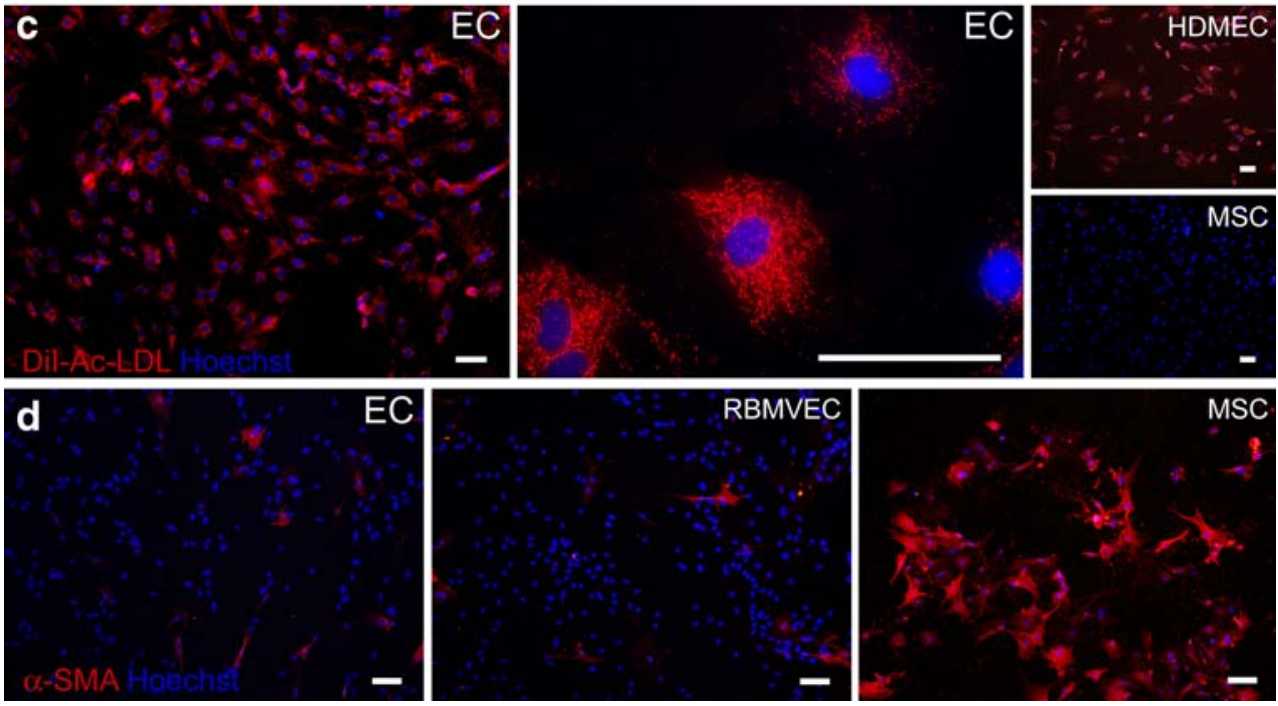
Fig. 2 Glucose-stimulated insulin release. Black bars,

$1.67 \mathrm{mmol} / \mathrm{l}$ glucose; hatched bars $16.7 \mathrm{mmol} / 1$ glucose. The islets were cultured for 4-7 days in $\mathrm{CM}$ and then $24 \mathrm{~h}$ in $\mathrm{CM}$ or ECCM. a The insulin release in response to $16.7 \mathrm{mmol} / \mathrm{l}$ glucose was enhanced in islets incubated in ECCM compared with $\mathrm{CM}$ prior to experiments. b With or without receptor antagonists (antag) to $\mathrm{ET}_{\mathrm{A}}, \mathrm{ET}_{\mathrm{B}}$ or neutralising antibody $(\mathrm{ab})$ to

thrombospondin-1. $\mathbf{c}$ With or without neutralising antibodies to LM or HGF. In additional experiments the COX-2 inhibitor rofecoxib or DMSO as vehicle was added to the ECCM. d With or without an addition of LM-111 $(30 \mu \mathrm{g} / \mathrm{ml})$. All values are means \pm SEM for 12 paired experiments in $\mathbf{a}$ and six paired experiments in $\mathbf{b}-\mathbf{d} .{ }^{*} p<0.05$ and $* * p<0.01$ compared with corresponding CM group; ${ }^{\dagger} p<0.05$ compared with ECCM

Fig. 3 Total islet insulin content after glucose-stimulated insulin release. a Islets cultured in ECCM contained more insulin than islets cultured in CM. b With or without receptor antagonists (antag) to $\mathrm{ET}_{\mathrm{A}}, \mathrm{ET}_{\mathrm{B}}$ or neutralising antibody $(\mathrm{ab})$ to thrombospondin-1. c With or without neutralising antibodies to LM or HGF. In additional experiments the COX-2 inhibitor rofecoxib or DMSO as vehicle was added to the ECCM. d With or without addition of LM-111 $(30 \mu \mathrm{g} / \mathrm{ml})$. All values are means \pm SEM for 12 paired experiments in a and six paired experiments in b-d. ${ }^{*} p<0.05$ and $* * p<0.01$ compared with corresponding CM group; ${ }^{\dagger} p<0.05$ compared with ECCM
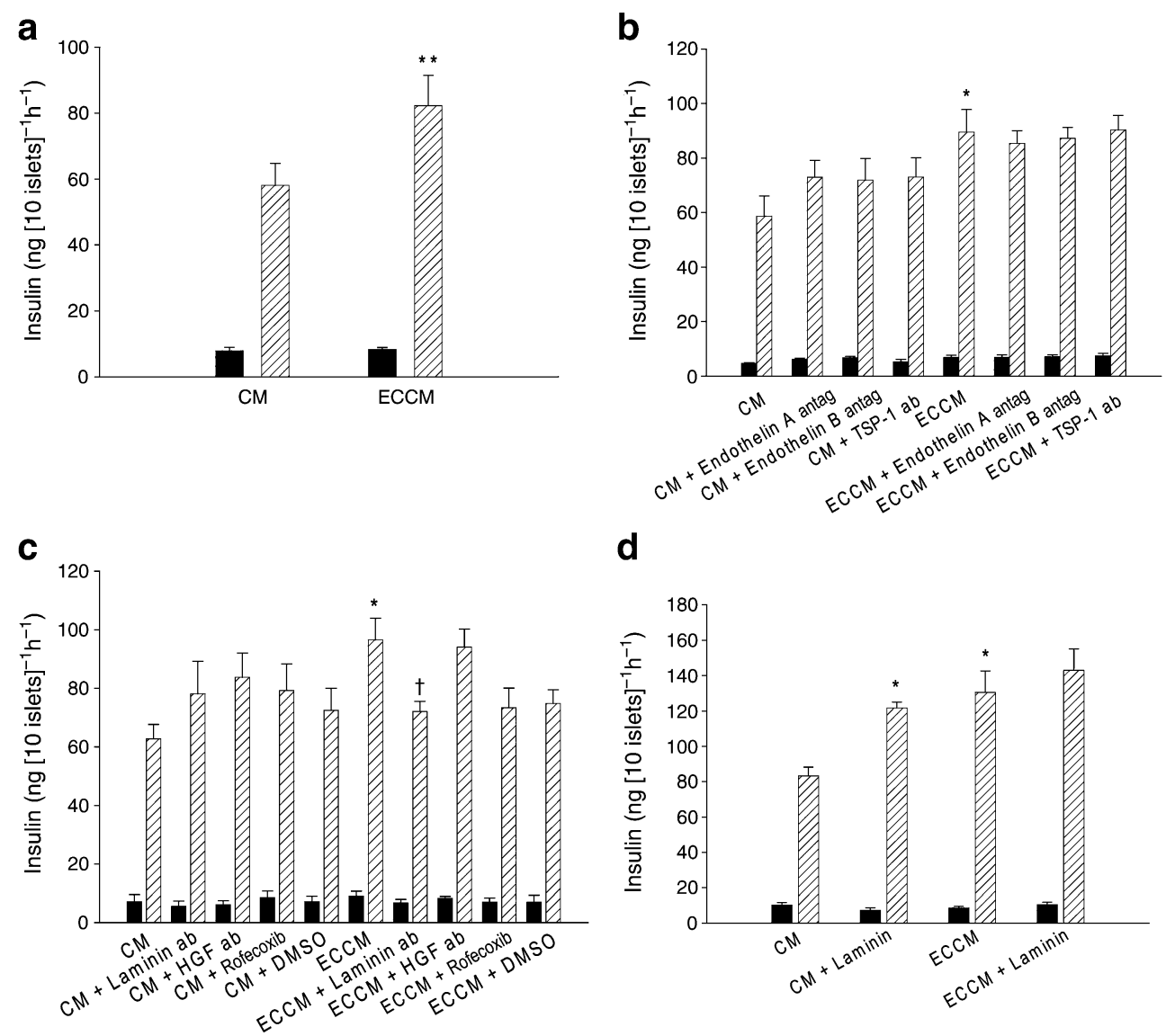

d
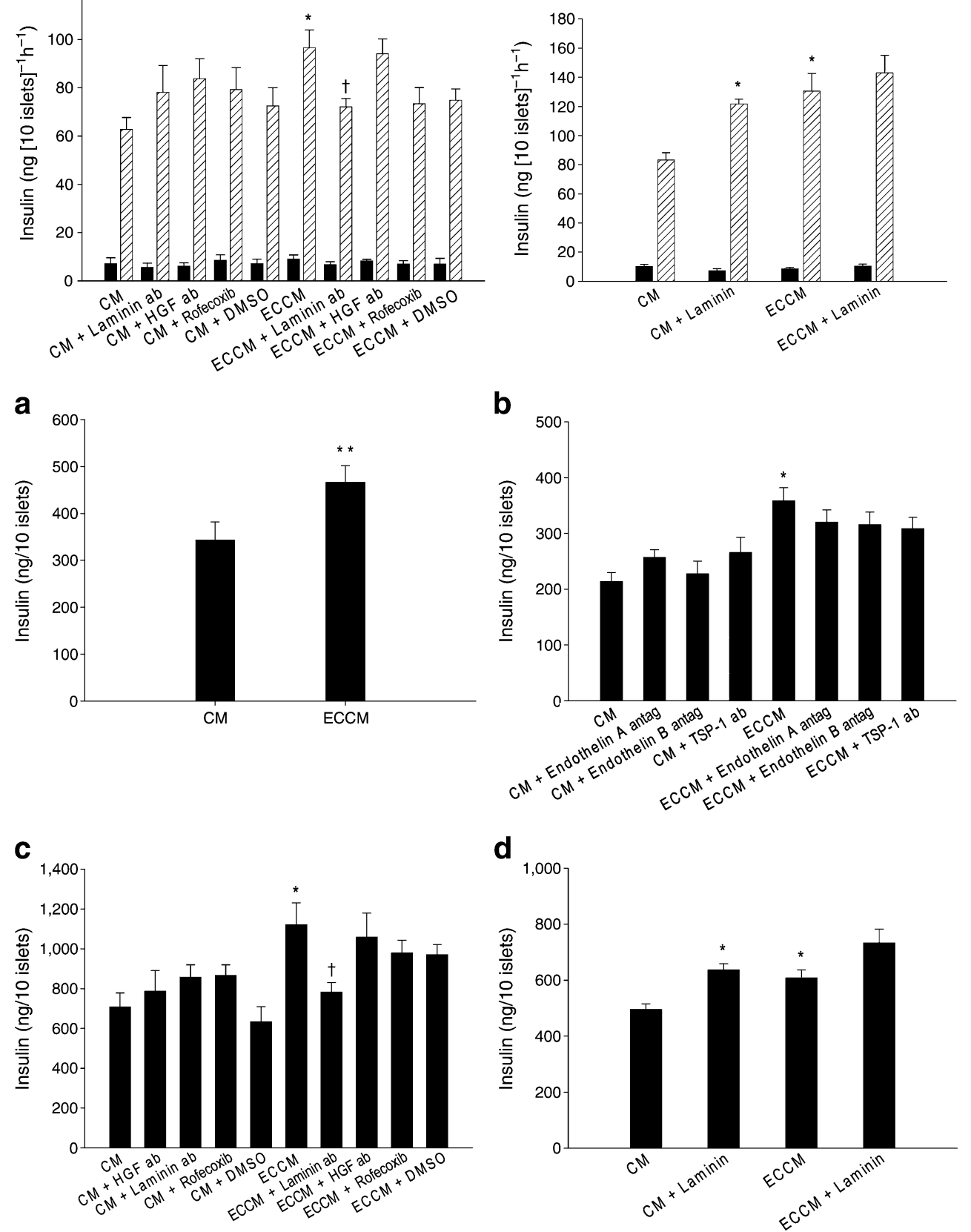
Addition of a COX-2 inhibitor, when compared with islets exposed to ECCM with DMSO as vehicle control, did not affect islet insulin content. However, neutralisation of the LM $\beta 1$-chain in the ECCM prevented its positive effects on islet insulin content (Fig. 3c). Moreover, there was an increase in insulin content from islets incubated in $\mathrm{CM}$ with addition of LM-111 when compared with control CM (Fig. 3d).

Glucose oxidation rate When exposed to $16.7 \mathrm{mmol} /$ 1 glucose, the islets cultured in ECCM had a $60 \%$ increase in glucose oxidation rate compared with islets cultured in CM (Fig. 4).

Islet (pro)insulin biosynthesis and total protein biosynthesis The (pro)insulin biosynthesis did not differ between the islets that had been cultured in CM compared with ECCM. Similar results were observed irrespectively of whether the (pro)insulin biosynthesis per se was measured (no data shown) or was expressed as a ratio of total protein biosynthesis (Fig. 5a).

Insulin degradation Islet intracellular degradation of insulin was determined using a pulse-chase method including a $72 \mathrm{~h}$ pulse with $\left[{ }^{3} \mathrm{H}\right]$ leucine and a subsequent $24 \mathrm{~h}$ chase in $\mathrm{CM}$ or ECCM. After the chase period the content of radioactively labelled insulin was measured and calculated as a percentage of the radioactive insulin in the islets retrieved immediately after the pulse incubation. Lacking insulin was regarded as degraded intracellularly, since no insulin degradation occurs in the incubation media at the present conditions. The islets incubated in CM during the chase period degraded $57 \%$ of the intracellular insulin,

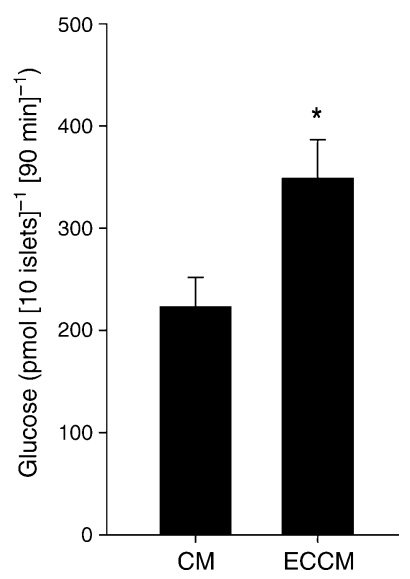

Fig. 4 Glucose oxidation rate. The islets were cultured for 4-7 days in $\mathrm{CM}$ and then $24 \mathrm{~h}$ in $\mathrm{CM}$ or ECCM. The glucose oxidation rate at $16.7 \mathrm{mmol} / 1$ glucose was higher in the islets that had been cultured in ECCM compared with the islets that had been cultured in CM. Values are means \pm SEM for six paired experiments. $* p<0.05$ compared with $\mathrm{CM}$
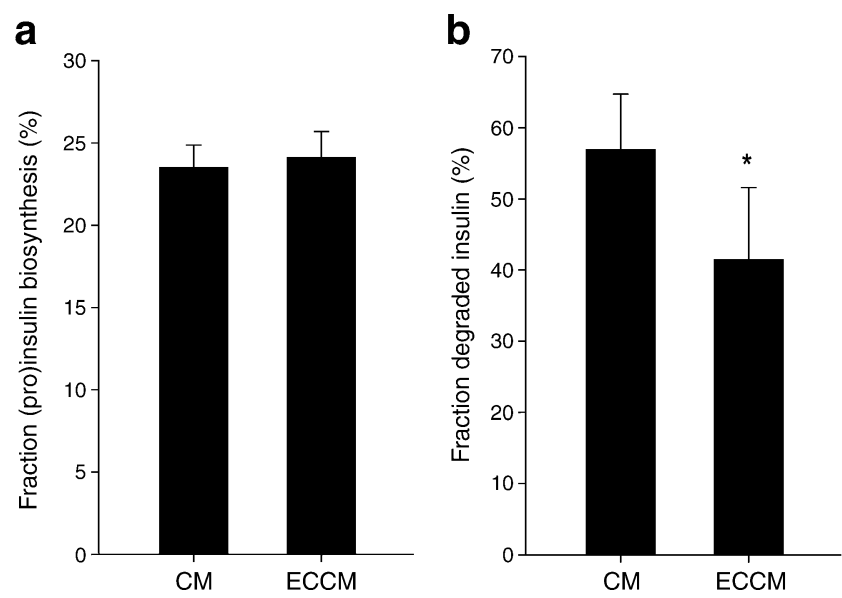

Fig. 5 a Islet (pro)insulin biosynthesis expressed as percentage of total protein biosynthesis. The islets were cultured for 4-7 days in CM and then $24 \mathrm{~h}$ in CM or ECCM. The (pro)insulin biosynthesis in response to $16.7 \mathrm{mmol} / 1$ glucose did not differ between the groups. $\mathbf{b}$ Islet intracellular insulin degradation. Insulin degradation was determined using a pulse-chase method including a $72 \mathrm{~h}$ pulse with $\left[{ }^{3} \mathrm{H}\right]$ leucine and a subsequent $24 \mathrm{~h}$ chase in CM or ECCM. The islets cultured in ECCM degraded less insulin compared with islets cultured in $\mathrm{CM}$. Values are means $\pm \mathrm{SEM}$ for six experiments. ${ }^{*} p<0.05$ compared with $\mathrm{CM}$

whereas the islets incubated in ECCM only degraded $41 \%$ of the intracellular insulin (Fig. 5b).

Gene expression There was no difference in mRNA expression of genes encoding glucose transporter 2 $(S l c 2 a 2)$, pyruvate carboxylase $(P c x$ [also known as $P c]$ ) or pancreatic and duodenal homeobox $1(P d x l)$ in islets that had been cultured in ECCM compared with CM. However, islets cultured in ECCM had increased mRNA expression of glucokinase gene (Gck) when compared with islets cultured in control CM (Fig. 6a). Likewise, the
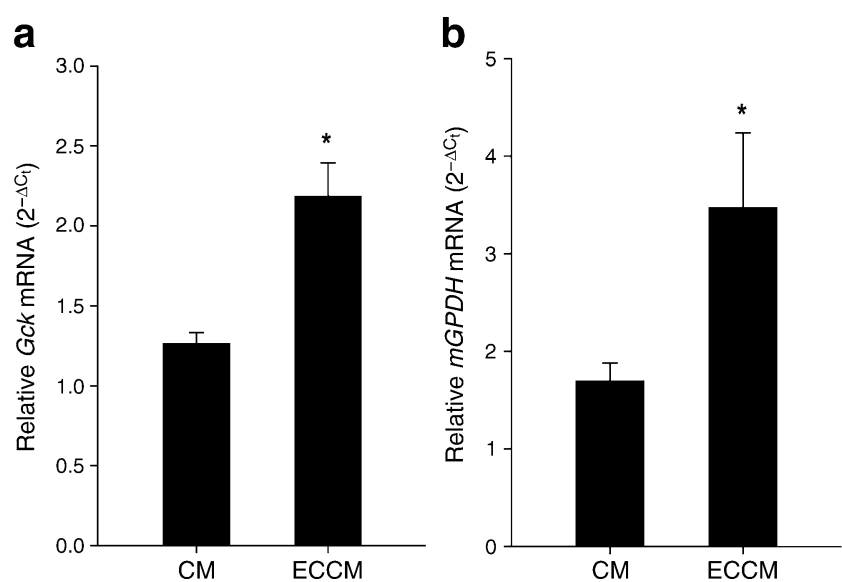

Fig. 6 Relative mRNA levels for islet $G c k$ (a) and $m G P D H$ (b) after 4 days of culture in $\mathrm{CM}$ and then an additional $24 \mathrm{~h}$ culture in $\mathrm{CM}$ or ECCM. Values are means \pm SEM for six experiments. ${ }^{*} p<0.05$ compared with $\mathrm{CM}$ 
mRNA expression for the gene for glycerol-3-phosphate dehydrogenase ( $m G p d h$ [also known as Gpd2]) was increased in islets cultured in ECCM compared with CM (Fig. 6b).

In order to investigate whether LM is indeed expressed in the endothelial cells, the mRNA expression of genes encoding LM chains $\alpha 4$ (Lama4), $\alpha 5$ (Lama5), $\beta 1$ (Lamb1)and $\beta 2$ (Lamb2) were measured in endothelial cells and whole islets. All tested LM chains displayed markedly higher mRNA expression in endothelial cells compared with whole islets (Fig. 7).

There was no difference in mRNA expression of insulin gene $(\operatorname{Ins} 1)$ in islets cultured with $\mathrm{CM}$ with addition of LM-111 compared with islets cultured in CM alone $(n=6$; data not shown).

\section{Discussion}

The present study demonstrates that endothelial cells can be important not only for transport functions by providing nutrients and oxygen to parenchymal cells, but also for paracrine functional support. In our investigations of rat pancreatic islets exposed or not to islet endothelial cell
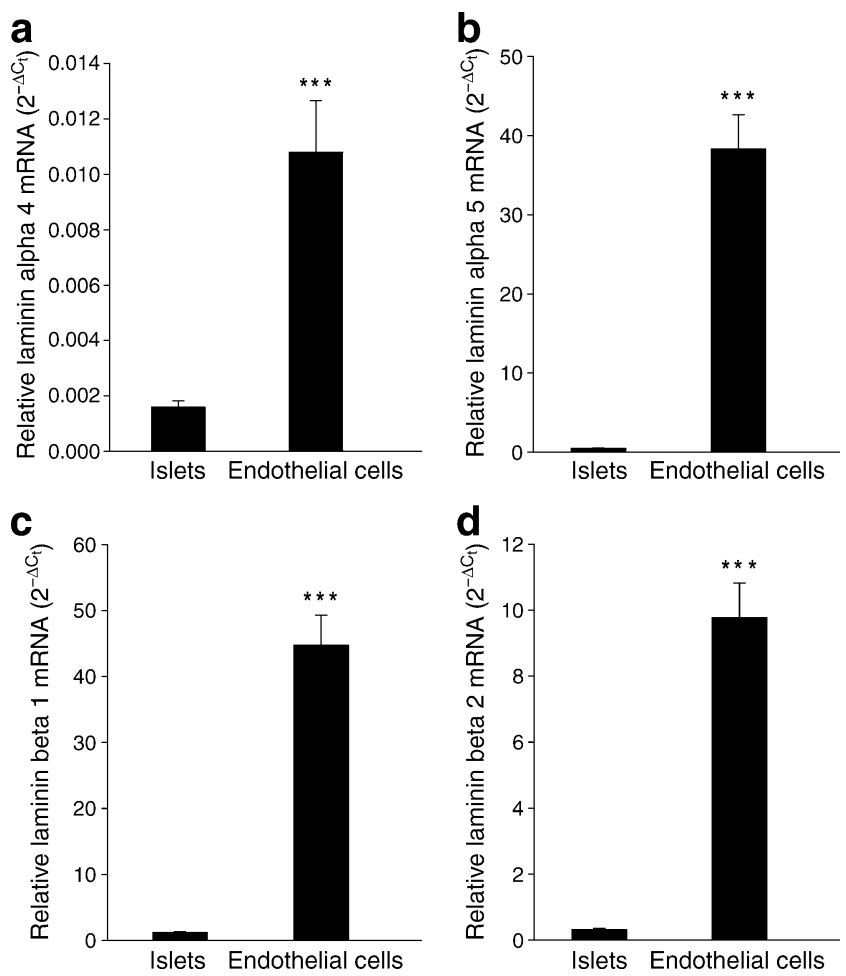

Fig. 7 Endothelial and whole-islet relative mRNA levels for genes for LM chain $\alpha 4$ (Lama4) (a), $\alpha 5$ (Lama5) (b), $\beta 1$ (Lamb1), (c) and $\beta 2$ $($ Lamb2) $(\mathbf{d})$. Values are means \pm SEM for six experiments. $* * * p<0.001$ compared with whole islets products, we observed that the insulin release was enhanced by more than $40 \%$ in response to $16.7 \mathrm{mmol} / 1$ glucose and that the insulin content was increased by $35 \%$ when the islets had been exposed to ECCM compared with CM. At least part of the augmented insulin release after endothelial cell product exposure was explained by increased mitochondrial activity as assessed by glucose oxidation. This was also reflected in an upregulation of the mitochondrial gene $m G p d h$. Also the rate limiting enzyme in the beta cell glycolysis, glucokinase, was upregulated.

It has previously been shown that vascular basement membrane proteins, particularly LMs, promote insulin gene expression in mouse beta cells [7]. However, in the present study in the rat no such effect could be observed after exposure to LM-111. Moreover, despite the fact that both insulin release and total insulin content were increased in the islets that had been cultured in ECCM, we could see no increase in (pro)insulin biosynthesis. This suggests that any raised expression of the insulin gene was not translated to protein levels. Analysis of the medium after exposure to ECCM (data not shown) indicated that the increased insulin content did not result from an effect of inhibited insulin release to the medium during the culture in ECCM. Instead, we observed decreased intracellular insulin degradation after culture of islets in ECCM.

In an attempt to find the factors responsible for the positive effects of ECCM on beta cell function, a number of different neutralising antibodies or receptor antagonists were tested to see if they could remove these effects from the ECCM. The rationale for the selection of the interventions was based on previous observations by us and others. Tsp-1 is a natural inhibitor of angiogenesis expressed in islet endothelium, which we have recently observed is important for beta cell differentiation in TSP-1deficient mice [22]. ET-1 is a potent vasoconstrictor derived from endothelial cells, which is known to stimulate insulin release [23]. HGF was recently shown by us to be expressed by islet endothelial cells and to stimulate beta cell proliferation [13]. Likewise, there are indications that beta cells do not form their own basement membrane, but rely on endothelial cells to form a vascular basement membrane containing LMs next to the beta cell [14]. LM111 has been demonstrated to promote differentiation of pancreatic precursor cells into beta cells in vitro [24] and to promote glucose-stimulated insulin secretion in vitro $[15$, $25,26]$. Prostaglandins exert a number of effects on islet beta cells, although mostly negative $[27,28]$.

The LM $\beta 1$-chain was recently observed to be the perhaps most important basement membrane component that promotes proliferation in beta cells through interaction with $\alpha 6-$ and especially $\beta 1$-integrins on the beta cell surface [14]. In our studies, an antibody towards the $\beta 1$ chain of LM was the only factor investigated that could 
neutralise the positive effects of ECCM on islet insulin content and glucose-stimulated insulin release. The positive effect of LM was further investigated by adding LM-111 to islets in $\mathrm{CM}$, and these islets displayed a pronounced increase in insulin content and glucose-stimulated insulin release compared with control islets. The results from the RT-PCR studies showed that islet endothelial cells had markedly higher mRNA levels of LM chains $\alpha 5$ and $\beta 1$ than whole islets. LM chains $\alpha 4$ and $\beta 2$ were also more expressed in islet endothelial cells compared with whole islets. At least part of the beneficial effect of islet endothelial cells on beta cells can therefore be attributed to LMs. At least some of the expression of LMs in whole islets probably reflects residual endothelial content. It has earlier been shown that LM-411 and LM-511 are the major LM isoforms in vascular basement membranes [29]. In addition, the peri-islet capsule seems to be composed of LM chains $\alpha 2, \beta 1$ and $\gamma 1$, suggesting the presence of LM211 [30]. At least in humans, LM-421 and LM-521 also seem to be present in the islet basement membranes [31].

Previous studies aiming to study the importance of endothelial paracrine support for the beta cell function have used PDX1-CRE:VEGF ${ }^{\mathrm{f} / \mathrm{fl}}$, VEGF ${ }^{\mathrm{fl} / \mathrm{fl}}$, RIP-CRE:VEGF ${ }^{\mathrm{fl} / \mathrm{wt}}$ or RIP-CRE:VEGF ${ }^{\mathrm{fl} / \mathrm{fl}}$ [7, 11, 32]. These studies have provided conflicting results, showing both decreased and augmented beta cell function in the VEGF-deficient islets. Nevertheless, the influence of VEGF deficiency per se for beta cell function, as well as of the likely change of phenotype in islet endothelial cells after loss of VEGF exposure, in these models remains to be determined. Moreover, beta cell function is likely to be affected by the decreased transport capacities caused by the low vascular density and decreased endothelial fenestrations in these islets.

In conclusion, the present study points to an important supportive role for islet endothelial cells in beta cell function that is most probably mediated by LMs. The insufficient revascularisation of islets following transplantation of pancreatic islets [33, 34] may therefore cause further consequences than impaired oxygen transport [35, 36] and contribute to islet dysfunction. Likewise, loss of islet endothelial cells, as recently reported in long-term experimental type 2 diabetes [37], may contribute to progressive beta cell failure.

Acknowledgements The skilled technical assistance of A. Nordin is greatly acknowledged. This study was supported by grants from the Swedish Research Council (55X-15043), the Juvenile Diabetes Research Foundation, the EFSD/JDRF/Novo Nordisk Research Programme 2006, the Swedish Diabetes Association, the Swedish Juvenile Diabetes Fund, the Novo Nordisk Insulin Fund, the Anér Foundation, the Åke Wiberg Foundation, the Wallenberg Foundation and the Family Ernfors Fund.

Duality of interest The authors declare that there is no duality of interest associated with this manuscript.

\section{References}

1. Pries A, Kuebler W (2006) Handbook of experimental pharmacology: normal endothelium. Springer, Berlin

2. Matsumoto K, Yoshitomi H, Rossant J, Zaret KS (2001) Liver organogenesis promoted by endothelial cells prior to vascular function. Science 294:559-563

3. Lammert E, Cleaver O, Melton D (2001) Induction of pancreatic differentiation by signals from blood vessels. Science 294:564 567

4. Franck-Lissbrant I, Häggström S, Damber JE, Bergh A (1998) Testosterone stimulates angiogenesis and vascular regrowth in the ventral prostate in castrated adult rats. Endocrinology 139:451456

5. LeCouter J, Moritz DR, Li B et al (2003) Angiogenesisindependent endothelial protection of liver: role of VEGFR-1. Science 299:890-893

6. Olsson R, Maxhuni A, Carlsson PO (2006) Revascularization of transplanted pancreatic islets following culture with stimulators of angiogenesis. Transplantation 82:340-347

7. Nikolova G, Jabs N, Konstantinova I et al (2006) The vascular basement membrane: a niche for insulin gene expression and beta cell proliferation. Dev Cell 10:397-405

8. Bonner-Weir S (1988) Morphological evidence for pancreatic polarity of beta-cell within islets of Langerhans. Diabetes 37:616621

9. Kamba T, Tam BY, Hashizume H et al (2006) VEGF-dependent plasticity of fenestrated capillaries in the normal adult microvasculature. Am J Physiol Heart Circ Physiol 290:H560-H576

10. Lammert E, Gu G, McLaughlin M et al (2003) Role of VEGF-A in vascularization of pancreatic islets. Curr Biol 13:1070-1074

11. Brissova M, Shostak A, Shiota M et al (2006) Pancreatic islet production of vascular endothelial growth factor-A is essential for islet vascularization, revascularization, and function. Diabetes 55:2974-2985

12. Kilkenny DM, Rocheleau JV (2008) Fibroblast growth factor receptor-1 signaling in pancreatic islet beta-cells is modulated by the extracellular matrix. Mol Endocrinol 22:196-205

13. Johansson M, Mattsson G, Andersson A, Jansson L, Carlsson PO (2006) Islet endothelial cells and pancreatic beta-cell proliferation: studies in vitro and during pregnancy in adult rats. Endocrinology 147:2315-2324

14. Nikolova G, Strilic B, Lammert E (2007) The vascular niche and its basement membrane. Trends Cell Biol 17:19-25

15. Labriola L, Montor WR, Krogh K et al (2007) Beneficial effects of prolactin and laminin on human pancreatic islet-cell cultures. Mol Cell Endocrinol 263:120-133

16. Suschek C, Fehsel K, Kroncke KD, Sommer A, Kolb-Bachofen V (1994) Primary cultures of rat islet capillary endothelial cells. Constitutive and cytokine-inducible macrophage-like nitric oxide synthases are expressed and activities regulated by glucose concentration. Am J Pathol 145:685-695

17. Mattsson G, Danielsson A, Kriz V, Carlsson PO, Jansson L (2006) Endothelial cells in endogenous and transplanted pancreatic islets: differences in the expression of angiogenic peptides and receptors. Pancreatology 6:86-95

18. Voyta JC, Via DP, Butterfield CE, Zetter BR (1984) Identification and isolation of endothelial cells based on their increased uptake of acetylated-low density lipoprotein. J Cell Biol 99: 2034-2040

19. Nyqvist D, Kohler M, Wahlstedt H, Berggren PO (2005) Donor islet endothelial cells participate in formation of functional vessels within pancreatic islet grafts. Diabetes 54:2287-2293

20. Aumailley M, Bruckner-Tuderman L, Carter WG et al (2005) A simplified laminin nomenclature. Matrix Biol 24:326-332 
21. Borg LAH, Eide SJ, Andersson A, Hellerström C (1979) Effects in vitro of alloxan on the glucose metabolism of mouse pancreatic B cells. Biochem J 182:797-802

22. Olerud J (2009) Role of thrombospondin-1 in endogenous and transplanted pancreatic islets. Uppsala University, Acta Universitatis Upsaliensis, Uppsala

23. Gregersen S, Thomsen JL, Brock B, Hermansen K (1996) Endothelin-1 stimulates insulin secretion by direct action on the islets of Langerhans in mice. Diabetologia 39:1030-1035

24. Jiang FX, Cram DS, DeAizpurua HJ, Harrison LC (1999) Laminin-1 promotes differentiation of fetal mouse pancreatic beta-cells. Diabetes 48:722-730

25. Parnaud G, Hammar E, Rouiller DG, Armanet M, Halban PA, Bosco D (2006) Blockade of beta1 integrin-laminin-5 interaction affects spreading and insulin secretion of rat beta-cells attached on extracellular matrix. Diabetes 55:1413-1420

26. Hammar EB, Irminger JC, Rickenbach K et al (2005) Activation of NF-kappaB by extracellular matrix is involved in spreading and glucose-stimulated insulin secretion of pancreatic beta cells. J Biol Chem 280:30630-30637

27. Luyckx AS, Deliege M, Jardon-Jeghers C, Lefebvre PJ (1981) Insulin, prostaglandin E2 and glucagon release by human tissue incubated in vitro. Influence of indomethacin. Diabetes Metab 7:13-17

28. Robertson RP, Tsai P, Little SA, Zhang HJ, Walseth TF (1987) Receptor-mediated adenylate cyclase-coupled mechanism for PGE2 inhibition of insulin secretion in HIT cells. Diabetes 36:1047-1053

29. Sixt M, Engelhardt B, Pausch F, Hallmann R, Wendler O, Sorokin LM (2001) Endothelial cell laminin isoforms, laminins 8 and 10, play decisive roles in $\mathrm{T}$ cell recruitment across the blood-brain barrier in experimental autoimmune encephalomyelitis. J Cell Biol 153:933-946

30. Irving-Rodgers HF, Ziolkowski AF, Parish CR et al (2008) Molecular composition of the peri-islet basement membrane in NOD mice: a barrier against destructive insulitis. Diabetologia $51: 1680-1688$

31. Virtanen I, Banerjee M, Palgi J et al (2008) Blood vessels of human islets of Langerhans are surrounded by a double basement membrane. Diabetologia 51:1181-1191

32. Iwashita N, Uchida T, Choi JB et al (2007) Impaired insulin secretion in vivo but enhanced insulin secretion from isolated islets in pancreatic beta cell-specific vascular endothelial growth factor-A knock-out mice. Diabetologia 50:380-389

33. Mattsson G, Jansson L, Carlsson PO (2002) Decreased vascular density in mouse pancreatic islets after transplantation. Diabetes 51:1362-1366

34. Carlsson PO, Palm F, Mattsson G (2002) Low revascularization of experimentally transplanted human pancreatic islets. J Clin Endocrinol Metab 87:5418-5423

35. Carlsson PO, Palm F, Andersson A, Liss P (2001) Markedly decreased oxygen tension in transplanted rat pancreatic islets irrespective of the implantation site. Diabetes 50:489-495

36. Olsson R (2006) The microvasculature of endogenous and transplanted pancreatic islets. Uppsala University, Acta Universitatis Upsaliensis, Uppsala

37. Cantaluppi V, Biancone L, Romanazzi GM et al (2006) Antiangiogenic and immunomodulatory effects of rapamycin on islet endothelium: relevance for islet transplantation. Am J Transplant 6:2601-2611 